\title{
BIOMASS POWER PLANTS AND HEALTH PROBLEMS AMONG NEARBY RESIDENTS: A CASE STUDY IN THAILAND
}

\section{CHUDCHAWAL JUNTARAWIJIT}

\author{
Naresuan University, Phitsanulok, Thailand \\ Department of Natural Resources and Environment, Faculty of Agriculture \\ Natural Resources and Environment
}

\begin{abstract}
Objectives: Electricity generation from biomass has become a boom business. However, currently, concerns over their environmental and health impact have emerged. This study aimed to explore these health problems by studying two small biomass power plants in Thailand. Materials and Methods: Data concerning chronic diseases and health symptoms was collected from 392 people by trained interviewers by the use of a questionnaire. Results: Residents living within $1 \mathrm{~km}$ from the power plants had a higher prevalence of allergies (Odds ratio $=2.4,95 \% \mathrm{CI}: 1.5-4.0)$, asthma $(\mathrm{OR}=2.1,95 \% \mathrm{CI}$ : $1.0-4.4)$ and chronic obstructive pulmonary disease (COPD) $(\mathrm{OR}=2.7,95 \% \mathrm{CI}: 1.0-8.4)$. The risks of other symptoms, itching/rash, eye irritation, cough, stuffy nose, allergic symptoms, sore throat, and difficulty breathing among those living within $0.5 \mathrm{~km}$ from the power plants $(\mathrm{OR}=2.5-8.5)$ were even more marked. Conclusions: It has been concluded that without a proper control, pollution from the biomass power plants can cause significant health problems to the nearby residents.
\end{abstract}

\section{Keywords:}

Biomass, Power plant, Health problem, Smoke exposure, Rice husk

\section{INTRODUCTION}

Electricity generation from biomass has become a boom business and currently, there are circa 2000 biomass power plants producing a total of $22.5 \mathrm{GW}$ in over 40 countries [1]. They are regarded as a renewable and $\mathrm{CO}_{2}$ neutral energy resource and biomass fuel is considered to be a promising alternative energy source applicable to both, emerging and developed economies. Normally, biomass refers to the material derived from growing plants or from animal manure [2]. To generate electricity, biomass can be either directly burned for thermal energy production or converted into other forms, such as biogas, for later use.
The majority of today's biomass power plants are directfired systems, where biomass is burned in order to produce steam for driving turbines and generating electric power [2].

Concerns have emerged over environmental and health impacts of air pollution from biomass power plants, especially those using a direct-fired system because they release large amounts of combustion air pollutants containing thousands of chemicals [3]. Some of these chemicals have been listed as toxic by the United States Environmental Protection Agency (USEPA) and other as carcinogens by the International Agency for Research on Cancer

This study was supported by the Department of Health, Ministry of Public Health, Thailand.

Received: January 3, 2013. Accepted: September 5, 2013.

Corresponding author: C. Juntarawijit, Department of Natural Resources and Environment, Faculty of Agriculture Natural Resources and Environment, Naresuan University, Phitsanulok 65000, Thailand (e-mail: cjuntara@gmail.com). 
(IARC). Well-known pollutants are present in a form of particulate matter, oxides of nitrogen (NOx) and carbon monoxide (CO). Ozone may be also indirectly produced from NOx by the action of sunlight. These pollutants can cause serious health consequences such as: respiratory irritation, chronic obstructive pulmonary disease (COPD), asthma, allergy, declining lung function and increased mortality [4].

In the cases where biomass has been used for cooking, heating and lighting within home premises, the biomass smoke exposure is strongly associated with adverse health outcomes. These include: respiratory diseases (COPD or susceptibility to pneumonia or tuberculosis infections), low birth weight, cataracts, cardiovascular disease, and mortality [5,6]. For ambient exposure, however, current data is limited, probably because of the fact that biomass energy is a relatively new business and the majority of power plants are located in rural areas with a limited number of nearby residents. A literature review by Boman, Forsberg and Jarvholm [7] found only 9 reports, which focused mainly on exposure to particulate matter $<10 \mu \mathrm{m}$ in diameter $\left(\mathrm{PM}_{10}\right)$. These reports found a relationship between exposure to $\mathrm{PM}_{10}$, originating from wood-burning, and respiratory problems, increased mortality and morbidity (associated with asthma), other respiratory symptoms as well as declining lung function. In a recent longitudinal study [8] ambient wood smoke increased COPD hospitalizations. In contrast, Bennett et al. [9] failed to find an increased risk of respiratory symptoms in populations with a high use of domestic wood burning heaters.

Biomass electricity generation is encouraged by many governments, including that of Thailand where the industry has grown rapidly. Basing on the data from the Ministry of Energy, Thailand [10], by 2022, electricity from biomass power will have accounted for $20 \%$ of its total national electricity from all sources ( 3700 MW). Nevertheless, this industry has been poorly regulated and many plants have been a subject of anecdotal complaints from the nearby residents concerning their poor health. However, there have been no systematic population studies to support this view within national setting of Thailand. Therefore, the present cross-sectional study aimed to delineate and quantitate health problems of the residents living nearby rural biomass power stations compared to those living further away.

\section{MATERIALS AND METHODS}

\section{Study design}

Two small power plants were targeted on a basis of their history of receiving public complaints and their location in rural areas where other major sources of air pollution were low. One of these (plant I) is a 6-MW power plant using steam turbine technology and the other (plant II), a 1-MW unit using gasification technology and an internal combustion engine. Both of them run an integrated rice mill and power business where the rice husks are used for the fuel source for the power plant. Wet scrubbers are used to trap air pollutants in flue gas before stack emission. Due to little planning regulation, there are many houses surrounding the power plants (Figure 1).

This is a cross-sectional study. Data on chronic diseases and health symptoms was collected using a questionnaire. One adult in each family was interviewed by village health volunteers who had been trained in the field of data collection. Only adults ( $\geq 15$ years old, in total: 392 people) were interviewed and these who were included in this study, i.e. 181 people living nearby plant I and 211 living nearby plant II. For chronic diseases, the subjects answered questions about the disease status of every member of the household thus health information concerning a total of 1254 people (3.2 person/household) was gathered. The prevalence per household, the number of households with members having one of the diseases divided by 392 households, was calculated and used for the purpose of a comparison between the groups. However, 


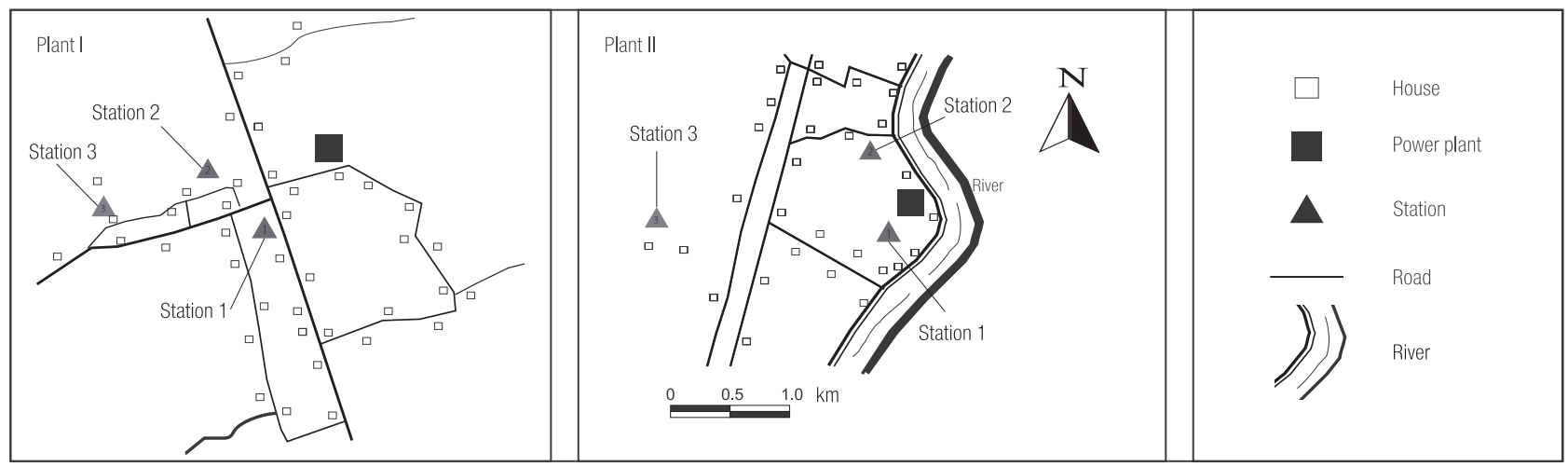

The housing symbol may not represent the actual location and number.

Fig. 1. Study areas and air monitoring stations

for health symptoms, the subjects reported only their own health symptoms during the past week $(\mathrm{N}=392$ people) and the prevalence of symptoms per population of 100 was used to analyse the data. The samples were selected basing on the distance from the power plant. Those working in the power plant were excluded. Figure 1 shows the study sites and air sampling stations.

Exposure depends on the proximity to the plant and air monitoring data. The subjects were asked to approximate the distance of their home from the relevant plant to the nearest category. To increase the number of subjects in each cut-point, the subjects were divided into three groups: those living within a zone of $0.5 \mathrm{~km}$ from the plant constituted group I, between 0.5 to $1 \mathrm{~km}$ - group II and more than $1 \mathrm{~km}$ - group III. There were 143 (36.5\%), 100 (25.5\%), and 149 (38\%) people in group I, II, and III, respectively.

Three air monitoring stations were placed to measure air quality within each zone (Figure 1). At each station, dustfall, the aerosols with diameter $>10 \mu \mathrm{m}$ and with the capability of settling down after temporary suspension in the air [11], total suspended particulate (TSP), $\mathrm{PM}_{10}, \mathrm{NO}_{2}, \mathrm{SO}_{2}$, and $\mathrm{O}_{3}$ levels were measured continuously throughout a $72 \mathrm{~h}$ period using USEPA reference methods. Air sampling was performed during the summer months with wind direction from the North and North-West.

\section{Statistical analysis}

Data was analysed using statistical package, SPSS v.17. The association between variables was obtained by utilizing odds ratio, including a $95 \%$ confidence interval. The results were considered statistically significant when $\mathrm{p}$-values were lower than 0.05 ( $\mathrm{p}<0.05$ ). Data from both sites was combined for statistical analysis in order to increase the sample size and statistical power.

\section{RESULTS}

\section{Air quality}

In the present study, three types of aerosol were measured, i.e. TSP, PM10, and dustfall. At each sampling station, all of the measures, except for dustfall, were within standard limits. The level of the pollutants ranged from $95-291 \mu \mathrm{g} / \mathrm{m}^{3}$ for TSP and from $38-75 \mu \mathrm{g} / \mathrm{m}^{3}$ for $\mathrm{PM}_{10}$, with no obvious decrease trend along with distance (Table 1). However, in the case of dustfall, majority of the levels reported around each station exceeded the standard level of $150-350 \mathrm{mg} / \mathrm{m}^{2} /$ day. Average levels in sampling stations 1, 2 and 3 were 455, 464 and $341 \mathrm{mg} / \mathrm{m}^{2} /$ day for plant I, and 355, unknown (sample stolen), and 313 for plant II, respectively - the values from the 3rd sampling site tended to be lower (Table 1). 
Table 1. Levels of air pollutants

\begin{tabular}{|c|c|c|c|c|c|c|c|}
\hline \multirow[b]{2}{*}{ Pollutant } & \multicolumn{3}{|c|}{ Plant I } & \multicolumn{3}{|c|}{ Plant II } & \multirow{2}{*}{$\begin{array}{l}\text { Air quality } \\
\text { standard }\end{array}$} \\
\hline & $\begin{array}{c}\mathrm{TSP} \\
\left(\mu \mathrm{g} / \mathrm{m}^{3}\right)\end{array}$ & $\begin{array}{c}\mathrm{PM}_{10} \\
\left(\mu \mathrm{g} / \mathrm{m}^{3}\right)\end{array}$ & $\begin{array}{c}\text { dustfall } \\
\left(\mathrm{mg} / \mathrm{m}^{2} / \text { day }\right)\end{array}$ & $\begin{array}{c}\mathrm{TSP} \\
\left(\mu \mathrm{g} / \mathrm{m}^{3}\right)\end{array}$ & $\begin{array}{c}\mathrm{PM}_{10} \\
\left(\mu \mathrm{g} / \mathrm{m}^{3}\right)\end{array}$ & $\begin{array}{c}\text { dustfall } \\
\left(\mathrm{mg} / \mathrm{m}^{2} / \text { day }\right)\end{array}$ & \\
\hline \multicolumn{8}{|l|}{ Particulate } \\
\hline station 1 & $185(160-206)$ & $74(61-87)$ & 455 & $95(73-123)$ & $46(40-54)$ & 355 & \\
\hline station 2 & $291(280-302)$ & $75(71-81)$ & 464 & $103(77-120)$ & $38(33-43)$ & NA & \\
\hline station 3 & $114(97-136)$ & $46(35-53)$ & 341 & $106(92-120)$ & $52(50-54)$ & 313 & \\
\hline standard & 330 & 120 & $150-350$ & 330 & 120 & $150-350$ & \\
\hline \multicolumn{8}{|l|}{ Toxic gas } \\
\hline $\mathrm{NO}_{2}(\mathrm{ppb})$ & & $2-35$ & & & $1-13$ & & 170 \\
\hline $\mathrm{SO}_{2}(\mathrm{ppb})$ & & $1-7$ & & & $1-5$ & & 300 \\
\hline $\mathrm{O}_{3}(\mathrm{ppb})$ & & $5-75$ & & & $3-70$ & & 100 \\
\hline
\end{tabular}

TSP - total suspended particulate; $\mathrm{PM}_{10}$ - particulate matter < $10 \mu \mathrm{m} ; \mathrm{NA}$ - not available.

Values: mean (range) of 3 samples.

Station 1: located at about $0.2 \mathrm{~km}$ from the power plant I, $0.05 \mathrm{~km}$ from plant II.

Station 2: located at about $0.4 \mathrm{~km}$ from the power plant I, $0.3 \mathrm{~km}$ from plant II.

Station 3: located at about $0.6 \mathrm{~km}$ from the power plant I, $1.2 \mathrm{~km}$ from plant II.

In the case of toxic gases, $\mathrm{NO}_{2}, \mathrm{SO}_{2}$ and $\mathrm{O}_{3}$, their concen- Health problems

trations were very low compared to the accepted limits Chronic diseases

and thus, only the range and maximum concentrations Allergies, asthma, and heart disease with the total prevwere reported. Maximum levels of $\mathrm{NO}_{2}, \mathrm{SO}_{2}$, and $\mathrm{O}_{3}$ alence rates (per 100 households) of 31.6, 13.0, and 7.1, were 35, 7, and $75 \mathrm{ppb}$, i.e. far below the air quality stan- respectively (Table 2) turned out to be the most common dard of 170,300, and $100 \mathrm{ppb}$, respectively (Table 1). There identifiable diseases among 392 households. However, the was no difference observed between the power plants and differences between the groups were found significantly sampling stations. different only in the case of allergy, asthma and COPD.

Table 2. Prevalence of chronic diseases and their associations with living distances

\begin{tabular}{lcccc}
\hline \multicolumn{1}{c}{ Disease* } & $\begin{array}{c}\text { Prevalence (per 100 } \\
\text { households) }\end{array}$ & OR & 95\% CI \\
\hline Allergy & 31.6 & & & \\
total & 45.4 & 2.4 & $1.5-4.0$ & $<0.01$ \\
group I & 21.0 & 0.8 & $0.4-1.4$ & 0.41 \\
group II & 25.5 & 1.0 & & \\
group III & & & & \\
Asthma & 13.0 & & & \\
total & & & \\
\hline
\end{tabular}


Table 2. Prevalence of chronic diseases and their associations with living distances - cont.

\begin{tabular}{|c|c|c|c|c|}
\hline Disease* & $\begin{array}{c}\text { Prevalence (per } 100 \\
\text { households) }\end{array}$ & OR & $95 \% \mathrm{CI}$ & $\mathrm{p}$ \\
\hline group I & 11.9 & 1.2 & $0.6-2.5$ & 0.62 \\
\hline group II & 19.0 & 2.1 & $1.0-4.4$ & 0.50 \\
\hline group III & 10.1 & 1.0 & & \\
\hline \multicolumn{5}{|l|}{ Heart disease } \\
\hline total & 7.1 & & & \\
\hline group I & 8.4 & 1.1 & $0.5-2.7$ & 0.75 \\
\hline group II & 5.0 & 0.7 & $0.2-2.0$ & 0.45 \\
\hline group III & 7.4 & 1.0 & & \\
\hline \multicolumn{5}{|l|}{ COPD } \\
\hline total & 6.6 & & & \\
\hline group I & 11.9 & 2.7 & $1.0-8.4$ & 0.04 \\
\hline group II & 2.0 & 0.4 & $0.0-2.2$ & 0.44 \\
\hline group III & 4.7 & 1.0 & & \\
\hline \multicolumn{5}{|l|}{ Tuberculosis } \\
\hline total & & 2.6 & & \\
\hline group I & 3.5 & 1.8 & $0.4-7.5$ & 0.44 \\
\hline group II & 2.0 & 1.0 & $0.2-6.1$ & 0.99 \\
\hline group III & 2.0 & 1.0 & & \\
\hline \multicolumn{5}{|l|}{ Cancer } \\
\hline total & 2.0 & & & \\
\hline group I & 1.4 & 0.3 & $0.1-1.7$ & 0.19 \\
\hline group II & 2.0 & 0.5 & $0.1-2.5$ & 0.38 \\
\hline group III & 4.0 & 1.0 & & \\
\hline
\end{tabular}

* Total: $\mathrm{N}=392$, group I: $\mathrm{N}=143$, group II: $\mathrm{N}=100$, group III: $\mathrm{N}=149$.

$\mathrm{OR}$ - odds ratio; $\mathrm{CI}$ - confidence interval.

COPD - chronic obstructive pulmonary disease.

In all three diseases, except for asthma, increased rates of disease in group I with odd ratios of 2.4 for allergy $(\mathrm{p}<0.01)$ and 2.7 for COPD $(\mathrm{p}=0.04)$ were observed. However, no differences were found in group II. For asthma, only group II had a higher relative risk $(\mathrm{OR}=2.1)$.
Health symptoms

It was found that people living near the power plants had developed many kinds of health symptoms, with a prevalence of 20.7-31.6 cases per 100 out of this population (Table 3). The most common symptoms were: itching/ 
Table 3. Prevalence of health symptoms and their associations with living distances

\begin{tabular}{|c|c|c|c|c|}
\hline $\begin{array}{l}\text { Symptoms } \\
\text { in the study groups }\end{array}$ & $\begin{array}{l}\text { Prevalence } \\
\text { (per } 100 \\
\text { population) }\end{array}$ & OR & $95 \% \mathrm{CI}$ & $\mathrm{p}$ \\
\hline \multicolumn{5}{|l|}{ Itching/rash } \\
\hline total & 31.6 & & & \\
\hline group I & 58.0 & 7.2 & $4.2-12.5$ & 0.01 \\
\hline group II & 17.0 & 1.1 & $0.5-2.1$ & 0.85 \\
\hline group III & 16.1 & 1.0 & & \\
\hline \multicolumn{5}{|l|}{ Eye irritation } \\
\hline total & 29.8 & & & \\
\hline group I & 48.9 & 5.3 & $3.0-9.1$ & 0.01 \\
\hline group II & 24.0 & 1.7 & $0.9-3.3$ & 0.09 \\
\hline group III & 15.4 & 1.0 & & \\
\hline \multicolumn{5}{|l|}{ Cough } \\
\hline total & 28.6 & & & \\
\hline group I & 47.6 & 3.9 & $2.3-6.6$ & 0.01 \\
\hline group II & 16.0 & 0.8 & $0.4-1.6$ & 0.57 \\
\hline group III & 18.8 & 1.0 & & \\
\hline \multicolumn{5}{|l|}{ Stuffy nose } \\
\hline total & 24.0 & & & \\
\hline group I & 44.8 & 8.5 & $4.4-16.4$ & 0.01 \\
\hline group II & 17.0 & 2.1 & $1.0-4.6$ & 0.05 \\
\hline group III & 8.7 & 1.0 & & \\
\hline \multicolumn{5}{|l|}{ Allergic symptoms } \\
\hline total & 23.5 & & & \\
\hline group I & 39.2 & 2.7 & $1.6-4.5$ & 0.01 \\
\hline group II & 7.0 & 0.3 & $0.1-0.7$ & 0.01 \\
\hline group III & 19.5 & 1.0 & & \\
\hline \multicolumn{5}{|l|}{ Sore throat } \\
\hline total & 22.7 & & & \\
\hline group I & 35.0 & 2.5 & $1.5-4.4$ & 0.01 \\
\hline group II & 13.0 & 0.7 & $0.3-1.4$ & 0.34 \\
\hline group III & 17.4 & 1.0 & & \\
\hline \multicolumn{5}{|l|}{ Difficulty breathing } \\
\hline total & 20.7 & & & \\
\hline group I & 35.0 & 6.7 & $3.3-13.6$ & 0.01 \\
\hline group II & 20.0 & 3.1 & $1.4-6.9$ & 0.01 \\
\hline group III & 7.4 & 1.0 & & \\
\hline
\end{tabular}

Abbreviations as in Table 2. 
rash (31.6\%), eye irritation (29.8\%) and cough (28.6\%). When compared to the reference subjects (group III), group I had clearly higher risk of all of the health symptoms surveyed in this study. Odds ratios for itching/rash, eye irritation, stuffy nose, and difficulty breathing were extraordinarily high $(\mathrm{OR}=6.3-8.5)$ while other symptoms were very high $(\mathrm{OR}=2.5-3.9)$.

Also, in the case of some symptoms, the subjects from group II showed a greater incidence of symptoms (stuffy nose and difficulty breathing) ( $\mathrm{OR}=1.7$ and 3.1 respectively).

\section{DISCUSSION}

People living near the biomass power plants had clearly elevated and consistent respiratory diseases and health symptoms. The increased risk of chronic diseases, prevalence of allergy, asthma and COPD was reported ( $\mathrm{OR}=2.4,2.1$ and 2.7 respectively). Various pollutants commonly found in biomass smoke, such as: PM10, ozone, and nitrogen dioxide, or polycyclic aromatic hydrocarbon, can be responsible for inducing these diseases [3]. Also grain dust may induce such effects [12]. Correlation between biomass smoke and asthma was strongly supported by the indoor research [6,7]. A recent meta-analysis also implicated biomass smoke as a risk factor for COPD with odds ratio of $2.44[8,13]$.

Many kinds of health symptoms were common among the study groups with very high prevalence and relative risk $(\mathrm{OR}=2.5-8.5)$. The symptoms were predominant among the group living within $0.5 \mathrm{~km}$ from the power plant and sharply decreased in the groups living further away. Although exposure to various kinds of pollutants found in biomass smoke, such as: particulate matter, oxide of nitrogen, ozone or other toxic chemical, may induce those symptoms [4,6,7], the data suggests that coarse particles constituted the major health risk. In comparison with the air quality standards levels of toxic gas and small particulate at the monitoring sites were very low.

Accordingly, it would be expected that falling particulates would be similarly low in the absence of local pollution sources. But the actual values were the same or slightly higher than the air quality standards indicating that the particulates were substantially greater than the ambient values for this rural environment. In addition to rice husk ash, grain dust or rice-husk dust may play a major role for the health impacts since both of the plants run both, rice milling and energy businesses. The air-born particles might come from various activities such as stack emission, transportation and handling of ash recovered from the combustion chambers as well as stacks and raw material, etc. Rice husk ash and dust are potent allergens and cause skin, eye and respiratory airway symptoms. Additionally, they increase asthmatic symptoms $[3,12,14,15]$.

\section{Limitations and bias}

The present study relied on self-reporting (which may or may not be based on a clinical diagnosis) and this will involve some degree of under or over reporting and a misclassification bias. This might depend on the nature of a disease. Nevertheless, such bias should distribute evenly in all the 3 study groups and thus should not influence the interpretations.

Exposure to other sources of pollution could have confounded the results. However, this problem was unlikely to occur because the study sites were carefully selected basing on the absence of other pollution sources. Also the data concerning air pollution supported the idea that ambient pollution was very low.

A recall bias might have occurred when the subjects were asked to report the history of their symptoms. Different groups might be able to recall differently; those living closer to the power plant may perceive any health 
disorder to arise from the plant activities and "recall" better than in the control group. However, in order to minimize such preconceptions the subjects were asked about the symptoms in the previous week only.

In this study, air monitoring data was collected over a very short period of time ( $72 \mathrm{~h}$ at 3 stations) and therefore, cannot fully reflect the long-term integrated exposure of our subjects to the pollution hazards. This depends on many factors such as ambient weather conditions, fuel quality, system operation and maintenance, or performance of pollution control device and air monitoring. It should also be recognized that the plant operators might have temporarily manipulated the plant operations to minimize pollution.

\section{CONCLUSION}

Without a proper control, pollution from biomass power plants can cause a significant health problem for the nearby residents. The residents who lived close to the plants reported a very high incidence of various respiratory diseases and symptoms not seen in those residing further away. These severe health risks were clearly associated with proximity to the plants. Although there appeared to be a substantial contribution from the side of biomass combustion, other plant operations associated with rice and its by-products may have had a major influence.

\section{ACKNOWLEDGEMENTS}

I thank the personnel of the Taphan Hin Crown Prince and Khlong Khlung Hospitals and their affiliated village health volunteers for carrying out the questionnaire survey; and Dr. C. Norman Scholfield for English proofreading, paper editing and helpful advice. My appreciation also goes to Asst. Prof. Dr. Sutatip Pongcharoen and Asst. Prof. Dr. Yuwayong Juntarawijit for their suggestions.

\section{REFERENCES}

1. Ecoprog. Biomass to energy: The world market for biomass power plants 2012/2013. October 2012 [cited 2012 December 10]. Available from: http:/www.ecoprog.com/fileadmin/ user_upload/leseproben/ext_market_report_biomass_power_plants_ecoprog.pdf.

2. Demirbas A. Potential applications of renewable energy sources, biomass combustion problems in boiler power systems and combustion related environmental issues. Prog Energy Combus Sci. 2005;31:171-92, http://dx.doi.org/10.1016/ j.pecs.2005.02.002.

3. Naeher LP, Brauer M, Lipsett M, Zelikoff JT, Simpson CD, Koenig JQ, et al. Woodsmoke health effects: A review. Inhal Toxicol. 2007;19:67-106, http://dx.doi. org/10.1080/08958370600985875.

4. World Health Organization. Health aspects of air pollution with particulate matter, ozone and nitrogen dioxide [report]. Bonn, Germany: WHO Working Group; 2003.

5. Fullerton DG, Bruce N, Gordon SB. Indoor air pollution from biomass fuel smoke is a major health concern in the developing world. Trans R Soc Trop Med Hyg. 2008;102:843-51, http://dx.doi.org/10.1016/j.trstmh.2008.05.028.

6. Torres-Duque C, Maldonado D, Perez-Padilla R, Ezzati M, Viegi G. Biomass fuels and respiratory diseases, a review of the evidence. Proc Am Thorac Soc. 2008;5:577-90, http:// dx.doi.org/10.1513/pats.200707-100RP.

7. Boman BC, Forsberg AB, Jarvholm BG. Adverse health effects from ambient air pollution in relation to residential wood combustion in modern society. Scand J Work Environ Health. 2003;29:251-60, http://dx.doi.org/10.5271/sjweh.729.

8. Gan WQ, FitzGerald JM, Carlsten C, Sadatsafavi M, Brauer M. Associations of ambient air pollution with chronic obstructive pulmonary disease hospitalization and mortality. Am J Respir Crit Care Med. 2013;187(7):721-7, http://dx.doi. org/10.1164/rccm.201211-2004OC.

9. Bennett CM, Dharmage SC, Matheson M, Gras JL, Markos J, Meszaros D, et al. Ambient wood smoke exposure and respiratory 
symptoms in Tasmania, Australia. Sci Total Environ. 2010;409:

294-9, http://dx.doi.org/10.1016/j.scitotenv.2010.10.002.

10. Ministry of Energy, Thailand. Biomass [cited 2012 March 20]. Available from: http://www.eppo.go.th/engy/Load/ET08.pdf.

11. Sami M, Waseem A, Akbar S. Quantitative estimation of dust fall and smoke particles in Quetta Valley. J Zhejiang Univ Sci B. 2006;7(7):542-7, http://dx.doi.org/10.1631/ jzus.2006.B0542.

12. Kayaba H, Meguro H, Muto H, Kamada Y, Adachi T, Yamada $\mathrm{Y}$, et al. Activation of eosinophils by rice-husk dust exposure: A possible mechanism for the aggravation of asthma during rice harvest. Tohoku J Exp Med. 2004;204:27-36, http://dx.doi.org/10.1620/tjem.204.27.

13. Hu G, Zhou Y, Tian J, Yao W, Li J, Li B, et al. Risk of COPD from exposure to biomass smoke: A metaanalysis. Chest. 2010;138(1):20-31.

14. Becklake R M. Grain dust and lung health: Not just a nuisance dust. Can Respir J. 2007;14:423-5.

15. Manfreda J, Holford-Strevens V, Cheang M, Warren CP. Acute Symptoms Following Exposure to Grain Dust in Farming. Environ Health Perspect. 1986;66:73-80, http:// dx.doi.org/10.1289/ehp.866673.

This work is available in Open Access model and licensed under a Creative Commons Attribution-NonCommercial 3.0 Poland License - http://creativecommons.org/ licenses/by-nc/3.0/pl/deed.en. 